\title{
PEMBUATAN BUKU CERITA ANAK BERMUATAN PENANGGULANGAN BENCANA DI SDN BANGUNREJO 1, SDN BANGUNREJO 2, DAN SDN BALUWARTI YOGYAKARTA
}

\author{
Oleh: \\ Siti Anafiah ${ }^{1}$, Ardian Arief ${ }^{2}$ \\ 1,2Pendidikan Guru Sekolah Dasar Universitas Sarjanawiyata Tamansiswa \\ 1anafiahs@yahoo.com
}

\begin{abstract}
Abstrak
Sekolah merupakan salah satu sumber transformasi pengetahuan mengenai strategi penyiapan dini terhadap bencana alam pada siswa. IImu pengetahuan dapat dikembangkan sebagai software yang dapat dimanfaatkan sebagai media mitigasi bencana untuk meminimalisir kerugian yang mungkin saja timbul ketika bencanabencana alam itu terjadi, baik kerugian materiil atau nonmaterial. Di Kota Yogyakarta, ada beberapa sekolah yang dicanangkan sebagai sekolah siaga bencana (SSB). Permasalahan yang sering muncul dan dirasa menjadi kendala bagi sekolah siaga bencana tersebut, antara lain: 1) semua mata pelajaran yang diajarkan sesuai kurikulum harus diintegrasikan dengan siaga bencana, 2) guru harus memasukkan nilai-nilai kesiagaan menghadapi bencana dalam berbagai media dan materi pembelajaran, 3) masih terbatasnya alat peraga/ media dan fasilitas yang ada di sekolah siaga bencana. Melalui program IbM yang direncanakan berlangsung selama 8 bulan dengan kerjasama Mitra SDN Baluwarti, SDN Bangunrejo 1, dan SDN Bangunrejo 2 diharapkan dapat membantu menyelesaikan persoalan yang dihadapi dengan menyediakan alat peraga/ media untuk menyampaikan materi siaga bencana kepada siswa. Salah satu media yang dapat digunakan adalah buku cerita anak. Oleh karena itu, perlu adanya pelatihan penulisan buku cerita anak bagi guru untuk media mitigasi bencana. Metode yang digunakan adalah mengidentifikasi permasalahan mitra, orentasi, praktek lapangan, dan refleksi. Hasil pengabdian ini adalah terciptanya tiga buku cerita anak bermuatan bencana, yaitu Gempa Gempita, Kecil Jadi Kawan, Besar Jadi Lawan, dan Gemuruh di Sekolah. Ketiga bencana tersebut merupakan bencana yang seringkali melanda masing-masing sekolah tersebut. Dengan buku cerita bermuatan bencana anak dapat mengetahui dan memahami tentang jenis bencana dan penanggulangannya. Dengan buku cerita, anak dapat mengetahui pengetahuan tentang bencana dengan mudah, karena buku tersebut tidak hanya menyuguhkan isi berupa tulisan naratif tetapi ilustrasi gambar yang menarik.
\end{abstract}

Kata kunci: Buku Cerita Anak, Media, Mitigasi Bencana

\section{Abstract}

School is one of the sources of knowledge transformation about early disaster preparedness strategy for students. Science can be developed as a software that can be utilized as disaster mitigation media to minimize losses that may arise when natural disasters occur, either material or nonmaterial losses. In Yogyakarta City, there are some schools that are proclaimed as disaster prepared schools (SSB). The problems that often arise and are perceived as obstacles to the disaster prepared schools include: 1) all subjects taught according to the curriculum should be integrated with disaster preparedness, 2) teachers should incorporate disaster preparedness values in various media and learning materials, 3) the limited number of props / media and facilities available in disaster prepared schools. Through the IBM program which is planned to last for 8 months with the cooperation of Partners SDN Baluwarti, SDN Bangunrejo 1, and SDN Bangunrejo 2 is expected to help solve the problems faced by providing props / media to deliver disaster preparedness material to students. One of the media that can be used is children's story books. Therefore, there is a need for training of children's story book writing for teachers for disaster mitigation media. The methods used are identifying partner problems, orentation, field practice, and reflection. The result of this devotion is the creation of three books of children's story of disasters, namely Earthquake Gempita, Small So Comrade, Big So Opponent, and Rumble in School. The three disasters are disasters that often hit each school. With disaster-laden storybooks children can know and understand about the types of disasters and their handling. With storybooks, children can know the knowledge about disaster easily, because the book not only presents the content of narrative writing but an interesting illustration of the picture.

Keywords: Children Story Book, Media, Disaster Mitigation

\section{PENDAHULUAN}

Bencana yang datang tidak dapat dicegah, akan tetapi jatuhnya korban dapat diminimalisir apabila masyarakat memiliki kesiapan dini terhadap bencana alam. Penanggulangan bencana tidak saja dapat dilakukan dengan perangkat kasar (hardware), seperti early warning system. Perangkat- 
perangkat lunak (software) seperti ilmu pengetahuan pun tidak kalah penting. Perangkat lunak inilah yang memiliki nilai urgensi untuk segera disebarluaskan. IImu pengetahuan, dengan demikian, dapat dikembangkan sebagai software yang dapat dimanfaatkan sebagai media mitigasi bencana untuk meminimalisir kerugian yang mungkin saja timbul ketika bencana-bencana alam itu terjadi, baik kerugian materiil atau nonmaterial. Sekolah merupakan salah satu sumber transformasi pengetahuan mengenai strategi penyiapan dini terhadap bencana alam pada siswa.

Mitigasi bencana didefinisikan sebagai upaya yang ditujukan untuk mengurangi dampak dari bencana baik bencana alam, bencana ulah manusia maupun gabungan dari keduanya dalam suatu negara atau masyarakat (Permendagri). Bentuk-bentuk bencana, baik yang disebabkan oleh alam maupun human failure, antara lain adalah gempa, banjir, letusan gunung api, instabilitas tanah yang mengakibatkan lonsor, angin kencang, bahaya teknologi, serta kekeringan dan desertifikasi. Ada empat hal penting dalam mitigasi bencana, yaitu (1) tersedia informasi dan peta kawasan rawan bencana untuk setiap jenis bencana; (2) sosialisasi untuk meningkatkan pemahaman dan kesadaran masyarakat dalam menghadapi bencana, karena bermukim di daerah rawan bencana, (3) mengetahui apa yang perlu dilakukan dan dihindari, serta mengetahui cara penyelamatan diri jika bencana timbul, dan (4) pengaturan dan penataan kawasan rawan bencana untuk mengurangi ancaman bencana (id.wikipedia.org)

Upaya penanggulangan bencana berbasis lembaga pendidikan masih sulit dikembangkan. Pasalnya, dalam dua tahun terakhir baru ada tiga lembaga pendidikan jenjang Sekolah Dasar (SD) yang berhasil dicanangkan sebagai Sekolah Siaga Bencana (SSB). Padahal jumlah SD di Kota Yogyakarta mencapai 90 sekolah. Menurut Kepala Dinas Pendidikan Kota Yogyakarta, Edy Heri Suasana, tidak mudah dalam mencanangkan sekolah siaga bencana. Selain harus memetakan potensi bencana yang ada di wilayah sekolah, kesiapan sarana seperti sumber daya manusia serta kurikulum sekolah juga mutlak dibutuhkan. Persiapan perencanaan sekolah siaga bencana bisa memakan waktu satu tahun. Hal ini karena semua mata pelajaran yang diajarkan sesuai kurikulum harus diintegrasikan dengan siaga bencana. Peran guru juga sangat penting dalam memasukkan nilai-nilai siaga bencana dalam berbagai media dan materi pembelajaran (Sigit, 2016: 9).

Berdasarkan hasil observasi sekolah yang dicanangkan sebagai sekolah siaga bencana (SSB) di kota Yogyakarta, antara lain SDN Bangunrejo 1, SDN Bangunrejo 2, dan SDN Baluwarti. SDN Bangunrejo 1 dan SDN Bangunrejo 2 kedua sekolah tersebut sudah dicanangkan sebagai SSB sejak tahun 2015. Kedua sekolah ini berada di pinggir Kali Winongo sehingga memiliki potensi bencana banjir dan tanah longsor. SDN Baluwarti baru dicanangkan sebagai SSB tahun 2016. SDN Baluwarti berada di tengah dan memiliki potensi bencana gempa bumi.

Bila dilihat keadaan lingkungan di sekitar masing-masing SD tersebut berbeda, sehingga dalam mensiagakan bencana juga berbeda. Perbedaan itu juga akan menunjukkan bahwa setiap guru memiliki pengalaman, pengetahuan, kemampuan, gaya, dan bahkan pandangan yang berbeda dalam mengajarkan yang mengintegrasikan dengan siaga bencana. Perbedaan potensi bencana yang ada di daerah tersebut menuntut guru lebih kreatif dalam membuat perencanaan, pelaksanaan, dan evaluasi sehingga tujuan pembelajaran dapat tercapai, terutama dalam kaitannya dengan memberikan pengetahuan kepada siswa tentang memitigasi bencana.

Selain itu permasalahan yang sering muncul dan dirasa menjadi kendala bagi ketiga sekolah siaga bencana tersebut, antara lain: 1) semua mata pelajaran yang diajarkan sesuai kurikulum harus diintegrasikan dengan siaga bencana, 2) guru harus memasukkan nilai-nilai kesiagaan menghadapi bencana dalam berbagai media dan materi pembelajaran, 3) masih terbatasnya alat peraga/ media dan fasilitas yang ada di sekolah siaga bencana.

Buku cerita anak merupakan salah satu media pembelajaran yang efektif untuk menyampaikan materi siaga bencana. Selama ini di ketiga SSB tersebut guru masih terbatas pada media gambar dan lagu dalam memberikan pengetahuan tentang siaga bencana pada siswa. Menurut Titik W.S, dkk. (via Rosdiyana, 2008:6.4) cerita anak adalah cerita yang sederhana yang kompleks. Kesedarhanaan itu ditandai oleh syarat wacananya yang baku dan berkualitas tinggi, namun tidak ruwet sehingga komunikatif. Cerita anak harus berbicara tentang kehidupan anak dengan segala aspek yang berada dan mempengaruhi mereka. Dengan 
banyak membaca cerita anak, seorang anak akan memperoleh kematangan emosi, intelektual, dan pengalaman tentang kehidupan. Cerita anak dapat memperkaya pembendaharaan kata anak. Buku cerita yang baik dapat membangkitkan semangat dan hasrat anak untuk belajar. Melalui cerita, daya khayal yang ada pada diri anak dapat dibina dan diarahkan kepada tujuan-tujuan yang sehat.

Cerita anak adalah karya sastra anak yang berupa prosa yang mengisahkan peristiwa atau pengalaman berdasarkan urutan waktu yang benar dialami oleh seseorang atau dapat juga berupa rekaan atau imajinasi yang mengisahkan seputar dunia anak-anak (Nurgiyantoro, 2005:21). Cerita anak adalah bacaan untuk anak yang berisikan kisah seputar anak yang boleh untuk diceritakan, bersifat menghibur, dan sesuai dengan tingkat perkembangan emosi dan intelektual anak (Arian, 2013:19. lib.unnes.ac.id). Dengan demikian, semua hal yang dikisahkan dalam cerita, baik budaya, ideologi cerita dibuat untuk anak.

Melalui cerita, anak dapat mengetahui dan mengenal berbagai bencana serta cara mencegah dan terhindar dari bencana. Pengalaman yang dialami oleh penduduk Simeuleu saat tsunami terjadi pada 24 Desember 2004 tampaknya dapat menjadi pertimbangan. Jumlah korban tsunami di Simeuleu cenderung lebih sedikit. Menurut cerita warisan nenek moyang mereka, jika terjadi gempa hebat maka yang dapat segera dilakukan untuk menyelamatkan diri adalah dengan mencari tempat yang tinggi. Maksudnya tentu saja tidak lain adalah menghindarkan diri dari kemungkinan terjadinya tsunami akibat gempa dahsyat yang terjadi. Contoh tersebut kiranya dapat digunakan sebagai pendukung hipotesa mengenai kebermanfaatan cerita sebagai software yang dapat dimanfaatkan sebagai media mitigasi bencana.

\section{METODE}

Kegiatan pengabdian masyarakat IbM yang dilaksanakan di SDN Baluwarti. Pelatihan ini diikuti oleh perwakilan guru dari SDN Baluwarti, SDN Bangunrejo 1, dan SDN Bangunrejo 2 berjumlah 10 orang. Pelatihan IbM dilaksanakan selama 8 bulan. Kegiatan ini dimulai dari sosialisasi mitigasi bencana, cara menulis cerita anak, praktik menulis cerita anak bermuatan mitigasi bencana, selanjutnya proses penerbitan.

\section{HASIL DAN PEMBAHASAN}

Kegiatan pengabdian $\mathrm{IbM}$ tentang penulisan buku cerita anak bermuatan bencana dilaksanakan 5 kali pertemuan. Tahap pertama, berkoordinasi dengan pihak sekolah. Tahap kedua, workshop penulisan buku cerita tentang langkah-langkah pembuatan cerita anak, Tahap ketiga dan empat pendampingan penulisan cerita, dan tahap ke lima pengumpulan cerita dan ilustrasi gambar. Adapun langkah-langkah pembuatan cerita anak bermuatan bencana sebagai berikut.

1. Mengidentifikasi bencana yang ada di SDN Baluwarti, SDN Bangunrejo 1, dan SDN Bangunrejo 2.

2. Mengidentifikasi SOP penanganan bencana yang ada di masing-masing sekolah dengan memberikan tanda pada langkah-langkah penanggulangan bencana yang dapat dilakukan oleh anak.

3. Pemilihan diksi yang dapat dipahami oleh anak.

4. Menggunakan tokoh yang mudah diingat dan menjadi icon bagi anak.

5. Penentuan latar yang ada di lingkungan anak.

6. Pembuatan kerangka karangan.

7. Pengembangan kerangka karangan menjadi karangan.

8. Pembuatan ilustrasi gambar yang dapat mendukung bentuk narasinya.

Dalam kegiatan penulisan buku cerita anak bermuatan bencana ini dilakukan identifikasi bencana yang terdapat di sekolah masing-masing. SDN Baluwarti dengan bencana gempa bumi. Hal itu karena merupakan perbatasan antara kota Yogyakarta dan Bantul yang pada saat gempa tahun 2010 di Yogyakarta sekitar SDN Baluwarti yang terletak di Kotagede sangat merasakan kedasyatan gempa tersebut. SDN Bangunrejo 1 dan SDN Bangunrejo 2 merupakan sekolah yang terletak dipinggiran sungai, yang sewaktu-waktu dapat menyebabkan banjir dan tanah lonsor.

Cerita anak bermuatan mitigasi bencana mempergunakan unsur-unsur intrnsik yang dapat mudah dipahami dan diingat oleh anak. Mulai dari tokoh, latar, alur, dan amanat yang dipergunakan harus dapat dipahami oleh anak. Hal itu bertujuan agar anak dapat mudah memahami penangulangan bencana, sehinga korban jiwa dapat dicegah.

Dalam pelatihan buku cerita anak ini diperoleh hasil tiga cerita bermuatan bencana, yaitu gempa bumi, tanah longsor dan banjir. 
Cerita yang pertama berjudul "Gempa Gempita" dengan berlatarkan sekolah dasar, penulis menceritakan suasana gempa yang terjadi pada saat pembelajaran berlangsung dan penanggulangannya. Judul Gempa Gempita diambil dari keadaan bencana dan nama tokoh dalam cerita yaitu seorang anak SD bernama Gempita.

Cerita yang kedua berjudul "Kecil Jadi kawan, Besar Jadi Lawan", cerita tersebut berisi tentang cara penanggulangan bencana banjir yang dapat dilakukan oleh anak-anak. Judul "Kecil Jadi kawan, Besar Jadi Lawan" mengajarkan kepada anak bahwa air bisa memberi manfaat bagi semua orang, tetapi air juga bisa membuat malapetaka bagi manusia.

Cerita yang ketiga berjudul "Gemuruh di Sekolah" dengan tokohnya Siti, Sansan, dan Tumi, penulis ingin menyampaikan bahwa bencana tanah lonsor bisa dimana saja tidak terkecuali sekolah. Oleh karena itu, pengetahuan tentang penanganan yang tepat sangat diperlukan tidak terkecuali kepada anak-anak.

Ketiga bencana tersebut merupakan bencana yang seringkali melanda masingmasing sekolah tersebut. Dengan buku cerita bermuatan bencana anak dapat mengetahui dan memahami tentang jenis bencana dan penanggulangannya. Dengan buku cerita, anak dapat mengetahui pengetahuan tentang bencana dengan mudah, karena buku tersebut tidak hanya menyuguhkan isi berupa tulisan naratif tetapi ilustrasi gambar yang menarik.

Target dari pelatihan penulisan cerita anak bagi guru, di antaranya kebutuhan jangka pendek guru dapat membuat media pembelajaran berupa buku cerita anak yang berisi tentang siaga bencana dengan memperhatikan perkembangan kognitif anak. Guru dapat memiliki pengetahuan cara membuat buku cerita anak. Sedangkan kebutuhan jangka panjang, diantaranya dengan buku cerita, diharapkan anak gemar membaca. Guru dapat membuat media pembelajaran tentang siaga bencana lebih variatif. Guru dapat mengimplementasikan media pembelajaran siaga bencana dalam setiap pembelajaran yang telah disusunnya.Guru dapat meningkatkan kualitas pembelajarannya.

\section{PENUTUP}

Bencana tidak dapat dicegah, namun korban jiwa dapat diminimalisasi. Terlebih bagi anak-anak yang biasanya menjadi orban paling banyak, karena keterbatasan fisik dan pengetahuan. Sekolah merupakan salah satu sumber transformasi pengetahuan mengenai strategi penyiapan dini terhadap bencana alam pada siswa. IImu pengetahuan dapat dikembangkan sebagai software yang dapat dimanfaatkan sebagai media mitigasi bencana untuk meminimalisir kerugian yang mungkin saja timbul ketika bencana-bencana alam itu terjadi, baik kerugian materiil atau nonmaterial. Di Kota Yogyakarta, sekolah yang dicanangkan sebagai sekolah siaga bencana (SSB), antara lain SDN Bangunrejo 1, SDN Bangunrejo 2, dan SDN Baluwarti. Permasalahan yang sering muncul dan dirasa menjadi kendala bagi ketiga sekolah siaga bencana tersebut, antara lain: 1) semua mata pelajaran yang diajarkan sesuai kurikulum harus diintegrasikan dengan siaga bencana, 2) guru harus memasukkan nilai-nilai kesiagaan menghadapi bencana dalam berbagai media dan materi pembelajaran, 3) masih terbatasnya alat peraga/ media dan fasilitas yang ada di sekolah siaga bencana. Melalui program IbM yang direncanakan berlangsung selama 8 bulan dengan kerjasama Mitra SDN Baluwarti, SDN Bangunrejo 1, dan SDN Bangunrejo 2 diharapkan dapat membantu menyelesaikan persoalan yang dihadapi dengan menyediakan alat peraga/ media untuk menyampaikan materi siaga bencana kepada siswa. Salah satu media yang dapat digunakan adalah buku cerita anak. Oleh karena itu, perlu adanya pelatihan penulisan buku cerita anak bagi guru untuk media mitigasi bencana.

\section{DAFTAR PUSTAKA}

Anonim. 2015. BNPB Adakan Pembekalan Fasilitator Daerah Sekolah/ MadrasahAman Bencana. www.bnpb.go.id. diakses 15 Mei 2016.

Arian, Adrianita Widiastuti. 2013. Peningkatan Keterampilan Menceritakan Kembali Cerita Anak melalui Teknik Demontrasi dengan Media Boneka Upin Ipin Siswa Kelas VII-B SMP Futuhiyyah Mranggen Kabupaten Demak.lib.unnes.ac.id.

Nurgiayantoro, Burhan. 2005. Sastra Anak: Pengantar Dunia Anak. Yogyakarta: UGM Press.

Permendagri. 2006. Pedoman Umum Mitigasi Bencana. www.gitews.org.

Rosdiyana, Yusi. 2008. Bahasa dan Sastra Indonesia di SD. Jakarta: Universitas Terbuka. Sigit, Agus. 
A] D. D Vol.3 No.2 Januari 2018, hal. 88 - 92

2016. BPBD DIY Hanya Mampu Resmikan 3 Sekolah Siaga
p-ISSN: $2460-5514$

e-ISSN: 2502-6518

Bencana Per Tahun. Kedaulatan Rakyat hlm. 9. 